Our Nature (2009) 7

\title{
Diversity of Zooplanktons in Betna Wetland, Belbari, Morang
}

\author{
R.B. Tiwari and D. Thapa Chhetry \\ Department of Zoology, P.G. Campus, T.U., Biratnagar, Nepal \\ Received: 04.11.2009, Accepted: 09.12.2009 \\ Key words: Zooplankton, taxonomic groups, Betna wetland
}

Zooplanktons are free swimming microscopic animals found almost in the mercy of tides, currents and waves. They feed on bacteria and phytoplankton and in turn are eaten by fish and crustaceans. Extensive work on zooplankton of Nepal has been done except Mahato (1980), Rai (1983), Upadhaya (1991), Jha (1994), Thapa (1994) and Surana (1995). Thus, little information is available regarding their taxomany and diversty in Nepal. The present work is based on limnological study made in Betna wetland $\left(26^{\circ} 20^{\prime}\right.$ to $26^{\circ} 53^{\prime} \mathrm{N} \&$ $87^{\circ} 16^{\prime}$ to $87^{\circ} 41^{\prime} \mathrm{E}$, alt $115 \mathrm{msl}$ ) which lies 2 $\mathrm{km}$ east from Belbari bazar along the eastwest highway, Morang district. The wetland is divided into two parts by a check dam erected for diversion of water for irrigation.

Samples were collected regularly once in a month, between 9 to 11 am with the help of plankton silk net (mesh size $8 \mu \mathrm{m}$ ) and fixed in $4 \%$ formalin solution on the spot. Microscopic observation, camera-lucida drawing and microphotography were done in the Ecology Laboratory, Department of Zoology, P.G. Campus, Biratnagar. Zooplanktons were identified following Needham and Needham (1962), Tonapi (1980), Adoni (1985) and APHA (1998). All the studied samples were deposited in the repository of the same Department.
In the present study 17 zooplankton genera belonging to 14 families and 9 orders were recorded (Table 1). They were represented by different taxonomic groups namely Copepoda, Rotifera, Cladocera, Ostracoda, Protozoa, Nematoda, and Diptera. Among the recorded genera Copepods were found dominant over other genera. They were observed in all the months throughout the study period.

Betna wetland is still very rich in biodiversity but due to pressure from local inhabitants the wetland needs rehabilitation strategy. Attempt has been made to highlight the zooplankton diversity and to aware local people to conserve the aquatic biodiversity of Betna wetland.

\section{References}

Adoni, A.D.C. 1985. Work book on Limnology. Bandana Printing Service, New Delhi.

APHA 1998. Standard methods for the examination of water and waste water. $20^{\text {th }}$ edition, APHA, AWWA, WEF, Washington DC.

Jha, D.K. 1994. Study on the population and diversity of Zooplankton in a village pond, Kritipur, Kathmandu. Central Department of Zoology, T.U., Kirtipur, Nepal. (M.Sc. Thesis)

Mahato, M. 1980. Studies on some physico-chemical parameters of temple tank (Kritipur) in relation to zooplankton. CDZ, T.U., Kirtipur, Nepal. (M.Sc. Thesis)

Needham, J.G. and P.R. Needham 1962. A guide to study of Freshwater Biology. Comstock, Ithaca, 
Our Nature (2009) 7

Table 1. Zooplanktons of Betana wetland.

\begin{tabular}{llll}
\hline SN & Genus & Family & Order \\
\hline 1 & Arcella spp. & Arcellidae & Rhizopoda \\
2 & Paramecium spp. & Paramecidae & Holotrichida \\
3 & Voticella spp. & Vorticellidae & Peritrichida \\
4 & Keratella spp. & Brachionidae & Rotifera \\
5 & Brachionus spp. & Brachionidae & Rotifera \\
6 & Philodina spp. & Philodinidae & Rotifera \\
7 & Filinia spp. & Testudinellidae & Rotifera \\
8 & Daphnia spp. & Daphnidae & Cladocera \\
9 & Moina spp. & Daphnidae & Cladocera \\
10 & Diaphansoma spp. & Sididae & Cladocera \\
11 & Macrothrix spp. & Macrothyricidae & Cladocera \\
12 & Nauplius larva of Apus. & Cyclopidae & Cladocera \\
13 & Cyclops spp. & Cyclopidae & Cladocera \\
14 & Diaptomus spp. & Diaptomidae & Cladocera \\
15 & Cypris spp. & Cypridae & Ostracoda \\
16 & Monohystera sp. & Monohysteridae & Monohysteridea \\
17 & Mosquito larva. & Anophelidae & Diptera \\
\hline
\end{tabular}

New York.

Rai, K.R. 1983. Preliminary investigation on the zoobenthos inhabiting in the shallow depth of lake, Phewa, Pokhara Valley. CDZ, T.U., Nepal. (M.Sc. Thesis)

Surana, R. 1995. Wetland ecology of Chimdi Lake (Birjutal), Sunsari district, eastern Nepal. Department of Zoology, P.G., Campus, T.U., Biratnagar, Nepal. (M.Sc. Thesis)

Thapa, T.B. 1994. An ecological study of village pond of Kritipur with reference to water quality and zooplankton. CDZ, T.U., Kirtipur, Nepal. (M.Sc. Thesis)

Tonapi, G.T. 1980. Fresh water animals of India. An ecological approach. Oxford and IBM publishing Company, New Delhi.

Upadhaya, S.K. 1991. Study on some physicochemical parameters affecting the zooplanktonic abundance of sewage stabilization, Dhobighat. CDZ, T.U., Nepal. (M.Sc. Thesis).

\title{
Bioremedial Treatment of Industrial Waste Water Using Rhodobacter sphaeroides
}

\author{
P.K. Agrawal", S. Prabha and S. Mittal \\ Department of Zoology, B.S.A. (P.G.) College, Mathura, U.P., India \\ *E-mail:dragrawalpk@gmail.com,mshalum@gmail.com \\ Received: 02.03.2009, Accepted: 23.07.2009
}

Key words: Bioremed iation, Bioreactor, Rhodobacter sphaeroides

Mathura, the birth place of Lord Krishna, is a rapidly growing city in the Uttar Pradesh province of India. A large number of industries are being operated here, including textile printing units, silver vibrators etc. The effluents from these industries contain 